\title{
DESOXYCORTICOSTERONE ACETATE (DOCA) AND VITAMIN C IN RHEUMATOID ARTHRITIS*
}

\author{
BY \\ JOSÉ M. POAL \\ Director of the Spanish Institute of Rheumatology, Barcelona, Spain
}

Among various products studied on account of the similarity of their chemical formulae to that of cortisone, we have progesterone, testosterone, compound $\mathrm{S}$, 17-hydroxy-pregnenolone, several other steroids, listed at present by code letters: MK-08, MK-11, MK-14, MK-18, MK-20; and finally, desoxycorticosterone with vitamin $\mathrm{C}$.

Lewin and Wassén (1949) first reported the effects of combined injections of desoxycorticosterone acetate (DOCA) and ascorbic acid in rheumatoid arthritis. This treatment has been repeated with contradictory results, extraordinary success having been reported by some workers, while others emphasized the inefficacy of the method.

We have used this treatment with 22 patients, and our results form the subject of this communication.

The 22 patients were affected with rheumatoid arthritis in the active stage, diagnosis being confirmed by clinical and laboratory findings. There were fourteen females and eight males. The duration of the disease on beginning the treatment varied from 3 months to 15 years, and the patients' ages from 24 to 62 years. The severity of the disease varied from slight pain with little functional limitation $(+)$, to severe pain with complete functional disability $(++++)$. The duration of the treatment ranged from 12 to 86 days.

\section{Technique}

We used the original technique described by Lewin and Wassén, consisting in the intramuscular injection of 5 or $10 \mathrm{mg}$. desoxycorticosterone acetate in oily solution, followed immediately by the intravenous injection of $1 \mathrm{~g}$. ascorbic acid $(10 \mathrm{ml}$. of a 10 per cent. solution). Where the intravenous route was not possible the ascorbic acid was injected intramuscularly. To give a more accurate interpretation and to eliminate psychogenic influences, we used in the few cases where good results seemed to be obtained, some placebo phials containing sesamoid oil of exactly the same appearance as those containing desoxycorticosterone acetate.

\section{Results}

Clinical.-Of the 22 patients treated, fourteen showed no substantial change, either objective or subjective, during or after the treatment. Four improved, but of these, only one can be considered as a real improvement (Case 10), inasmuch as of the remaining three, two (Cases 7 and 15) were relieved only subjectively

* We are indebted to the Ciba Laboratories for samples of Percorten and placebo phials, and to the Merck Laboratories for samples of Cebion. 
CLINICAL AND LABORATORY RESULTS OBTAINED IN TWENTYWITH DESOXYCORTICOSTERONE

\begin{tabular}{|c|c|c|c|c|c|c|c|}
\hline \multirow{3}{*}{$\begin{array}{l}\text { Case } \\
\text { No. }\end{array}$} & \multirow{3}{*}{ Sex } & \multirow{3}{*}{$\begin{array}{c}\text { Age } \\
\text { (years) }\end{array}$} & \multicolumn{2}{|c|}{ Disease } & \multicolumn{3}{|c|}{ Daily Dosage } \\
\hline & & & \multirow{2}{*}{$\begin{array}{c}\text { Duration } \\
\text { (years) }\end{array}$} & \multirow[t]{2}{*}{ Severity } & \multirow{2}{*}{$\begin{array}{c}\text { DOCA } \\
\text { (mg.) }\end{array}$} & \multicolumn{2}{|c|}{ Ascorbic Acid (g.) } \\
\hline & & & & & & Intramuscular & Intravenous \\
\hline $\begin{array}{l}1 \\
2 \\
3\end{array}$ & $\begin{array}{l}\mathbf{F} \\
\mathbf{F} \\
\mathbf{M}\end{array}$ & $\begin{array}{l}37 \\
42 \\
28\end{array}$ & $\begin{array}{l}4 \\
2 \\
1 \frac{1}{2}\end{array}$ & $\begin{array}{l}++ \\
++ \\
++\end{array}$ & $\begin{array}{r}5 \\
5 \\
5 \\
\end{array}$ & $\bar{z}$ & $\begin{array}{l}1 \\
1 \\
1\end{array}$ \\
\hline 4 & $\mathbf{F}$ & 43 & 10 & ++++ & $\left\{\begin{array}{r}5 \text { (44 days) } \\
10(12 \text { days })\end{array}\right.$ & 1 (8 days) & 1 (48 days) \\
\hline $\begin{array}{l}5 \\
6\end{array}$ & $\underset{\mathbf{F}}{\mathbf{M}}$ & $\begin{array}{l}53 \\
38\end{array}$ & $\begin{array}{l}6 \\
\frac{3}{4} \\
\end{array}$ & $\begin{array}{l}++ \\
++\end{array}$ & $\begin{array}{r}10 \\
5\end{array}$ & $\overline{1}$ & 1 \\
\hline$* 7$ & $\mathrm{~F}$ & 36 & $2 \frac{1}{2}$ & +++ & $\left\{\begin{array}{r}5(30 \text { days }) \\
10(11 \text { days })\end{array}\right.$ & - & 1 \\
\hline $\begin{array}{r}\dagger 8 \\
9\end{array}$ & $\begin{array}{l}\mathbf{F} \\
\mathbf{M}\end{array}$ & $\begin{array}{l}32 \\
41\end{array}$ & $\frac{1}{3}$ & $\stackrel{+}{+}+$ & $\begin{array}{r}5 \\
10\end{array}$ & 二 & $\begin{array}{l}1 \\
1\end{array}$ \\
\hline$\ddagger 10$ & $\mathbf{M}$ & 27 & 2 & +++ & $\left\{\begin{array}{r}5(43 \text { days }) \\
10(25 \text { days })\end{array}\right.$ & - & 1 \\
\hline 11 & $\mathbf{F}$ & 62 & 15 & ++++ & 5 & 1 (15 days) & 1 (6 days) \\
\hline 12 & $\mathbf{F}$ & 47 & $1 \frac{1}{2}$ & +++ & $\left\{\begin{array}{r}5(31 \text { days }) \\
10 \text { (14 days) }\end{array}\right.$ & - & 1 \\
\hline $\begin{array}{r}13 \\
14 \\
\S 15 \\
16 \\
* * 17\end{array}$ & $\begin{array}{l}\mathbf{F} \\
\mathbf{F} \\
\mathbf{M} \\
\mathbf{F} \\
\mathbf{M}\end{array}$ & $\begin{array}{l}24 \\
62 \\
38 \\
36 \\
47\end{array}$ & $\begin{array}{l}\frac{1}{6} \\
6 \frac{1}{2} \\
2 \frac{1}{2} \\
1 \\
4\end{array}$ & $\begin{array}{l}+ \\
+++ \\
++ \\
++ \\
+++\end{array}$ & $\begin{array}{c}10 \\
5 \\
5 \text { (44 days) } \\
5 \\
5\end{array}$ & $\begin{array}{l}\overline{1} \\
\overline{-}\end{array}$ & $\begin{array}{l}\frac{1}{1} \\
1 \\
1\end{array}$ \\
\hline 18 & $\mathbf{M}$ & 51 & $3 \frac{1}{2}$ & + & $\left\{\begin{array}{r}5(32 \text { days }) \\
10(31 \text { days })\end{array}\right.$ & - & 1 \\
\hline $\begin{array}{r}\dagger+19 \\
20 \\
21 \\
22\end{array}$ & $\begin{array}{l}\mathbf{F} \\
\mathbf{F} \\
\mathbf{M} \\
\mathbf{F}\end{array}$ & $\begin{array}{l}39 \\
41 \\
35 \\
49\end{array}$ & $\begin{array}{l}7 \\
2 \\
\frac{1}{2} \\
5\end{array}$ & $\begin{array}{l}++t \\
++ \\
+ \\
+++\end{array}$ & $\begin{array}{c}10 \text { (52 days) } \\
5 \\
10 \\
10\end{array}$ & $\frac{1}{-}$ & $\frac{1}{1}$ \\
\hline
\end{tabular}

*(7) When he had improved subjectively, the patient was given control injections; the persistence of the subjective improvement confirms its psychogenic nature.

$t(8)$ On discontinuing treatment, the patient stopped growing worse.

$\ddagger(10)$ The patient grew worse when treated with the placebo and began to improve again when DOCA injections were resumed.

(the psychogenic nature of this improvement being confirmed by its persistence with placebo injections), and the third (Case 19), though improved both objectively and subjectively, also maintained the improvement with placebo therapy. This seems to support the view that any improvement was due not to the treatment, but to a spontaneous remission. The four remaining patients grew worse during the treatment; two of them both objectively and subjectively, and the other two only subjectively. In the two latter, the deterioration may have been psychogenic, but of the other two, one (Case 17) continued to become worse, and in the other (Case 8) the deterioration was arrested after the treatment was discontinued.

The blood pressure was maintained at about the same level during treatment in eighteen patients; the remaining four had slight increases (maximum $3 \mathrm{~mm}$. $\mathrm{Hg}$ in one case), but all four returned to pre-treatment levels shortly after the DOCA therapy was discontinued.

Oedema appeared in three patients, in two in the ankles, in the other in the 
TWO PATIENTS WITH RHEUMATOID ARTHRITIS, TREATED ACETATE AND ASCORBIC ACID

\begin{tabular}{|c|c|c|c|c|c|}
\hline \multirow{2}{*}{$\begin{array}{l}\text { Placebo } \\
\text { Injection }\end{array}$} & \multirow{2}{*}{$\begin{array}{l}\text { Duration of } \\
\text { Treatment } \\
\text { (days) }\end{array}$} & \multicolumn{2}{|c|}{ Clinical Result } & \multicolumn{2}{|c|}{ Sedimentation Rate (mm./hr.) } \\
\hline & & Objective & Subjective & $\begin{array}{c}\text { Before } \\
\text { starting } \\
\text { treatment }\end{array}$ & $\begin{array}{c}\text { Upon } \\
\text { discontinuing } \\
\text { treatment }\end{array}$ \\
\hline - & $\begin{array}{l}23 \\
38 \\
34\end{array}$ & $\begin{array}{l}\text { no change } \\
\text { no change } \\
\text { no change }\end{array}$ & $\begin{array}{l}\text { no change } \\
\text { no change } \\
\text { no change }\end{array}$ & $\begin{array}{l}26 \\
43 \\
54\end{array}$ & $\begin{array}{l}22 \\
33 \\
55\end{array}$ \\
\hline - & 56 & no change & worse & 48 & 30 \\
\hline - & $\begin{array}{l}43 \\
74\end{array}$ & $\begin{array}{l}\text { no change } \\
\text { no change }\end{array}$ & $\begin{array}{l}\text { no change } \\
\text { no change }\end{array}$ & $\begin{array}{l}36 \\
28\end{array}$ & $\begin{array}{l}28 \\
24\end{array}$ \\
\hline 1 (21 days) & 62 & no change & better & 64 & 52 \\
\hline - & $\begin{array}{l}25 \\
29\end{array}$ & $\begin{array}{c}\text { worse } \\
\text { no change }\end{array}$ & $\begin{array}{c}\text { worse } \\
\text { no change }\end{array}$ & $\begin{array}{l}20 \\
42\end{array}$ & $\begin{array}{l}20 \\
33\end{array}$ \\
\hline 1 (18 days) & 86 & better & better & 63 & 45 \\
\hline 一 & 21 & no change & no change & 29 & 20 \\
\hline- & 45 & no change & no change & 74 & 36 \\
\hline 1 (14 days) & $\begin{array}{l}52 \\
47 \\
58 \\
12 \\
49\end{array}$ & $\begin{array}{l}\text { no change } \\
\text { no change } \\
\text { no change } \\
\text { no change } \\
\text { worse }\end{array}$ & $\begin{array}{c}\text { worse } \\
\text { no change } \\
\text { better } \\
\text { no change } \\
\text { worse }\end{array}$ & $\begin{array}{l}43 \\
58 \\
40 \\
39 \\
68\end{array}$ & $\begin{array}{l}32 \\
50 \\
26 \\
35 \\
70\end{array}$ \\
\hline 一 & 63 & no change & no change & 31 & 18 \\
\hline $\begin{array}{c}1 \text { (19 days) } \\
- \\
- \\
-\end{array}$ & $\begin{array}{l}71 \\
33 \\
48 \\
72\end{array}$ & $\begin{array}{l}\text { better } \\
\text { no change } \\
\text { no change } \\
\text { no change }\end{array}$ & $\begin{array}{l}\text { better } \\
\text { no change } \\
\text { no change } \\
\text { no change }\end{array}$ & $\begin{array}{l}74 \\
42 \\
36 \\
62\end{array}$ & $\begin{array}{l}60 \\
36 \\
26 \\
44\end{array}$ \\
\hline
\end{tabular}

§(15) After six days of subjective improvement, the patient was given control injections, and the improvement was maintained. Same deductions as Case 7.

**(17) The patient continued to grow worse after treatment was discontinued.

$++(19)$ On the second day of improvement, DOCA was replaced by placebo injections, yet the subjective and objective improvement persisted. Therefore, in this case, apart from the psychogenic factor, it seems that a spontaneous remission occurred.

legs and lower part of the thighs. All three reverted to their previous state on ceasing the treatment.

Laboratory Findings.-A routine blood test was made weekly during the treatment. Red and white cell counts and haemoglobin remained practically unchanged. A decrease in the erythrocyte sedimentation rate was observed in most cases; in three it increased slightly or remained at the same level, and in the remaining nineteen, the fall ranged from 4 to $38 \mathrm{~mm}$. This lowering of the sedimentation rate is perhaps the most outstanding of our findings, for the clinical results were discouraging.

\section{Discussion}

Lewin and Wassén (1949) first reported a complete success in nine cases. Le Vay and Loxton (1949) confirmed their results, first in 23 patients of which 21 improved and later in eighty cases. Fox (1949) treated ten patients with 100 per cent. success. 
Douthwaite (1949), among five patients, obtained four encouraging results. Robertson (1950) in nine cases had one dramatic response and a great improvement in all the rest. Landsberg (1950) treated nine cases with excellent results, and Nashat (1950) four with apparently good results. Hartfall and Harris (1949), however, reported contradictory findings in seventeen patients, inasmuch as four grew worse, one improved very much, and the rest improved slightly. Other authors report no effect at all; Kellgren (1949) only obtained a doubtful response in six cases, Spies and others (1949) treated six patients with six failures, and Hart and Starer (1949) achieved no good effects at all in five cases treated.

Brownlee (1950), using rats for experimental purposes, has tried to explain the actual procedure of this method; he thinks that the combination of desoxycorticosterone acetate and ascorbic acid constitutes a valuable substitute in the absence of the adrenal-cortex hormones, among which may be included a steroid of anti-arthritic effect. He points out that the secret of the production of adequate biochemical alterations lies in the union of the two substances which may be the components of an important enzymatic system, or else that the desoxycorticosterone acetate must first be reduced by the vitamin C.

On the other hand, Le Vay and Loxton $(1949,1950)$ believe that the desoxycorticosterone and the ascorbic acid act peripherally and not through the adrenal cortex or any other internal organ. They support this theory by noting the quick response obtained after giving the injections. The clinical findings in ten patients with rheumatoid arthritis, in whom they conducted a special study, led them to assert that the interaction between the desoxycorticosterone and ascorbic acid confined in the peripheral tissues is capable of producing all the clinical changes observed in the joints. Another theory regarding the action of DOCA and vitamin C suggests that the change is caused by oxidation of the desoxycorticosterone acetate, a chemical process which would be accomplished through the adrenal cortex.

Thus even the mechanism whereby these drugs act is variously explained by several research workers who report similar results obtained by the same method. In view of the disparity of results, some authors try to explain the failures of others by saying that the negative results are due to the small but typical responses not having been noticed; that the variation in the response depends on the momentary condition of the gland and of the physico-chemical aptitude of its cells; and, finally, that the response is sometimes delayed.

From our own observations we conclude that failure could not have been due to the causes described above, since we strictly supervised each change that could take place, and observed that, in the great majority of our patients, it did not take place in 5 minutes, nor in 2,6 , or 24 hours, nor when the treatment was discontinued. We therefore believe that the contradictory results of different workers are to be explained by one of the following causes:

(1) Wrong Diagnosis.-It is possible that some cases reported as having responded dramatically to this treatment, were not true cases of rheumatoid arthritis; thus it may have happened that these incorrectly diagnosed patients either actually responded, or had a spontaneous remission in the normal course of their disease. 
(2) Wrong Interpretation of Results.-The response to a treatment must be judged both objectively and subjectively. The objective findings (perimeter of swollen joint, angle of joint motion, etc.) can be measured exactly in most cases before and after treatment. Unless this is done, there is a risk of inaccuracy in interpreting results.

(3) Psychogenic Factors.-The great influence of psychogenic factors is well known, especially when patients are being treated by a new method. To evaluate the results properly, therefore, these should be taken into account, using adequate controls.

(4) Autosuggestion.-The physician must be careful to lay aside any tendency to selfsuggestion when interpreting results, this factor being of greater importance when no proper measures have been taken to avoid the first three errors.

Our results lead to the conclusion that this method of treatment is not of practical use, since, of 22 patients treated, only one actually improved and even this improvement was no more than may be expected from any other "classic" treatment. On the other hand, it is evident that if we had treated 22 patients with gold salts, physiotherapy, etc., the percentage of improvements would have been much greater.

The only remarkable fact in the series of results was the decrease of the sedimentation rate in the majority of cases, which was in sharp contrast to the clinical evolution (see Figure).

There are authors who compare the results obtained in rheumatoid arthritis by desoxycorticosterone acetate and ascorbic acid, with

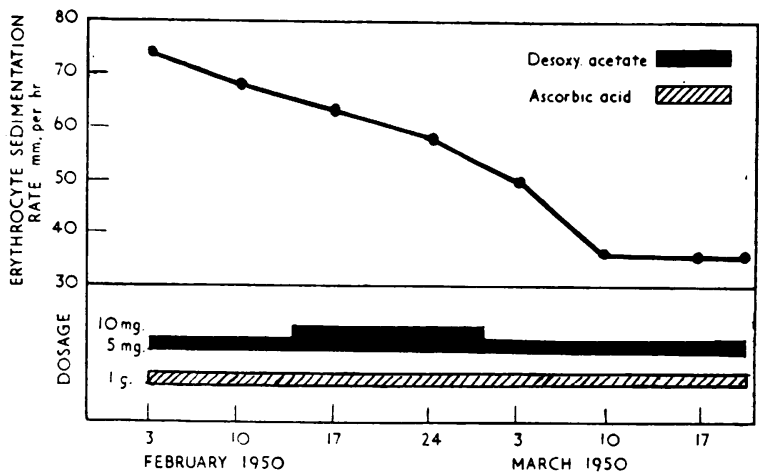

FigURE.-Diagram of sedimentation rate in Case 12. Despite the decrease in the sedimentation rate, no clinical improvement, objective or subjective, was observed. those obtained by cortisone or ACTH. We, who have treated many rheumatoid arthritis patients with these last two drugs, can assert categorically that the dramatic improvement produced by cortisone or ACTH, has not been observed with DOCA and vitamin C, nor with any other product which has so far appeared.

\section{Summary}

Twenty-two patients with rheumatoid arthritis were treated with combined injections of desoxycorticosterone acetate (DOCA) and vitamin C. Clinically, fourteen patients did not experience any change, four grew worse, and of the four that apparently improved, only one actually did so, and that only slightly. The one remarkable fact observed, was the decrease of the sedimentation rate in the majority of the cases. Results obtained by other authors are commented upon, and attempts made to explain the disagreement between previous reports. 
Brownlee, G. (1950). Lancet, 1, 157.

\section{REFERENCES}

Douthwaite, A. H. (1949). Ibid., 2, 1244.

Fletcher, E., Lush, B., Buchan, J. F., and Wolff, S. (1950). Ibid., 1, 94.

Fox, W. W. (1949). Ibid., 2, 1156.

Hart, V. Lloyd, and Starer, F. (1949). Ibid., 2, 1203.

Hartfall, S. J., and Harris, R. (1949). Ibid., 2, 1202.

Hench, P. S., Kendall, E. C., Slocumb, C. H., and Polley, H. P. (1949). Proc. Mayo Clín., $24,181$. Higuera Rojas, J. de la, and Gálvez Montes, J. (1950). Rev. clín. esp., 38, 1.

Kellgren, J. H. (1949). Lancet, 2, 1108.

Landsberg, M. (1950). Ibid., 1, 134.

Le Vay, D., and Loxton, G. E. (1949). Ibid., 2, 1134.

L (1950). Ibid., 1, 209.

Lewin, E., and Wassén, E. (1949). Ibid., 2, 993.

Loxton, G. E., and Le Vay, D. (1949). Ibid., 2, 1204.

Nashat, F. (1950). Ibid., 1, 135.

Robertson, J. A. (1950). Ibid., 1, 134.

Sommerville, I. F., Marrian, G. F., Duthie, J. J. R., and Sinclair, R. J. G. (1950). Ibid., 1, 116.

Spies, T. D., Stone, R. E., de Maeyer, E., and Niedermeier, W. (1949). Ibid., 2, 1219.

Zondek, H. (1935). "Diseases of the Endocrine Glands", trans. C. Prausnitz. Arnold, London.

\section{L'acétate de Desoxycorticostérone (DOCA) et la Vitamine $\mathrm{C}$ dans l'Arthrite Rhumatismale}

RÉSUMÉ

Vingt-deux malades atteints d'arthrite rhumatismale furent traités par des injections combinées d'acétate de desoxycorticostérone et de vitamine C. Du point de vue clinique, quatorze d'eux ne sentirent aucune différence et quatre furent plus mal; il y eut une amélioration chez quatre autres malades, mais elle ne fut qu'apparente chez trois d'eux et très légère chez le quatrième.

Un seul effet remarquable fut observé: la diminution de la vitesse de la sédimentation globulaire dans la plupart des cas. L'auteur commente sur les rapports anterieurs à ce sujet et apporte des raisons tendant à expliquer les resultats contradictoires y contenus.

\section{El Acetato de Desoxicorticosterona (DOCA) y la Vitamina C en la Artritis Reumatoide \\ RESUMEN}

Veintidós enfermos con artritis reumatoide fueron tratados con inyecciones combinadas de acetato de desoxicorticosterona (DOCA) y de vitamina C. Clinícamente, catorce enfermos no experimentaron cambio alguno, cuatro empeoraron y cuatro otros manifestaron mejoría que no fué más que aparente en tres y.ligera en el cuarto caso.

Se ha observado un solo hecho notable: la diminición de la velocidad de la eritrosedimentación en la mayoría de los casos. Se comenta sobre los resultados obtenidos por otros autores y se trata de explicar la discrepancia entre los relatos anteriores. 